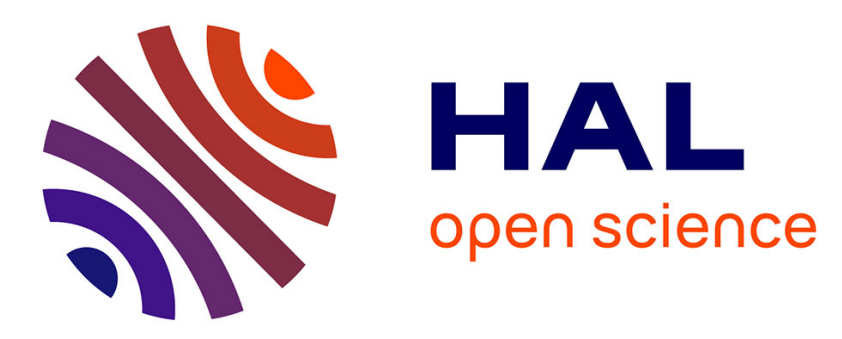

\title{
Palytoxins specific and dynamic detection by in vitro microplate assay with human neuroblastoma cells
} Begoña Espiña, Eva Cagide, M. Carmen Louzao, Maria Martinez-Fernandez, Mercedes R Vieytes, Panagiota Katikou, Adriano Villar, David Jaen, Luz Maman, Luis M Botana

\section{To cite this version:}

Begoña Espiña, Eva Cagide, M. Carmen Louzao, Maria Martinez-Fernandez, Mercedes R Vieytes, et al.. Palytoxins specific and dynamic detection by in vitro microplate assay with human neuroblastoma cells. Bioscience Reports, 2008, 29 (1), pp.13-23. 10.1042/BSR20080080 . hal-00479303

\section{HAL Id: hal-00479303 https://hal.science/hal-00479303}

Submitted on 30 Apr 2010

HAL is a multi-disciplinary open access archive for the deposit and dissemination of scientific research documents, whether they are published or not. The documents may come from teaching and research institutions in France or abroad, or from public or private research centers.
L'archive ouverte pluridisciplinaire HAL, est destinée au dépôt et à la diffusion de documents scientifiques de niveau recherche, publiés ou non, émanant des établissements d'enseignement et de recherche français ou étrangers, des laboratoires publics ou privés. 


\section{PALYTOXINS SPECIFIC AND DYNAMIC DETECTION BY IN VITRO MICROPLATE ASSAY WITH HUMAN NEUROBLASTOMA CELLS}

Begoña Espiña*, Eva Cagide*, M. Carmen Louzao*, Maria Martinez-

Fernandez*, Mercedes R. Vieytes ${ }^{\dagger}$, Panagiota Katikou ${ }^{\ddagger}$, Adriano Villar\$,

David Jaen ", Luz Maman" I, and Luis M. Botana*, \&, ๆ

*Departamento de Farmacologia. Facultad de Veterinaria. Universidâd de Santiago de Compostela. 27002 Lugo. Spain

†Departamento de Fisiologia Animal. Facultad de Veterinaria. Universidad de Santiago de Compostela. 27002 Lugo. Spain

\#National Reference Laboratory for Marine Biotoxins, Ministry of Rural

Development and Food, 3A Limnou st., 54627 Thessaloniki, Greece.

§Community Reference Laboratory for Marine Biotoxins-CRLMB, AESAN, Estacion maritima s/n, 36200, Vigo (Pontevedra), Spain.

I Laboratorio de Control de Calidad de los Recursos Pesqueros. Consejería de Agricultura y Pesca. 21459 El Rompido, Cartaya (Huelva). Spain

I Author for correspondence:

Luis M. Botana. Departamento de Farmacología. Facultad de Veterinaria27002 Lugo. Spain.

Tel \& Fax: +34 982252242.

E-mail: Luis.Botana@usc.es

Short title: Dynamic method for detecting palytoxins 


\section{SYNOPSIS}

Palytoxin is one of the most complex and biggest molecules known showing extreme acute toxicity. During the last years, the dinoflagellate Ostreopsis spp, the producer organism of palytoxin, has shown a world-wide distribution thus making palytoxin an emerging toxin.

Rat derived hepatocytes Clone 9 and BE (2)-M17 human neuroblastoma were used to test palytoxin or palytoxin -like compounds by measuring cell metabolic rate with Alamar Blue. The dose-dependent decrease in viability was specifically inhibited by ouabain in the case of BE (2)-M17 neuroblastoma cells. This is a functional, dynamic and simple test for palytoxins with high sensitivity as low as $0.2 \mathrm{ng} / \mathrm{mL}$. This method was useful for toxin detection in Ostreopsis extracts and naturally contaminated mussel samples. A comparative study testing toxic mussel extracts by LCMS/MS, MBA, hemolysis neutralization assay and cytotoxicity test indicated that our method is suitable for the routine determination and monitoring of palytoxins and palytoxin-like compounds.

Key words: Palytoxin, Alamar Blue, metabolic rate, viability assay, neuroblastoma cell line, functional detection method.

Abbreviations: PLT (palytoxin), MBA (mousse bioassay), OA (okadaic acid), MU (mousse unit), HNA (hemolysis neutralization assay). 


\section{INTRODUCTION}

Palytoxin (PLT) is one of the most potent toxins known. A wide range of fish and marine invertebrates used as food accumulate PLT and through the food chain this toxin has been responsible for numerous incidents of human morbidity and mortality [1]. PTL was initially isolated in 1971 from marine soft corals of the genus Palythoa [2]; much later however dinoflagellates of the genus Ostreopsis have been proposed as possible biogenic origins of this toxin[3]. Originally, Ostreopsis species were localized in tropical and subtropical areas, similarly to Gambierdiscus toxicus, the producer organism of ciguatoxins. However, at present Ostreopsis has a worldwide distribution. Recently, some people presented health problems related to exposure to marine aerosol in the Mediterranean Sea. The symptoms shown by the patients (fever, serious respiratory distress and conjunctivitis) were associated with $O$. ovata blooms [4, 5]. Liquid chromatography tandem mass spectrometric (LC-MS/MS) analyses in plankton samples from an $O$. ovata bloom in Ligurian coasts indicated the presence of putative PLT and a PLT-like molecule, that Ciminiello et al named ovatoxin-a [6]. In this context, the expanding distribution of potentially hazardous Ostreopsis spp is a fact.

At present, the most common method to detect PLT is the mouse bioassay. Based on the reported $\mathrm{LD}_{50}$ value for PLT of $450 \mathrm{ng} / \mathrm{kg}, 1$ Mouse Unit (MU) is presumed to be $9 \mathrm{ng}$ of PLT. The use of the mouse bioassay (MBA) detection method however raises bioethical problems. On the other hand this technique is not able to unequivocally distinguish the nature of the causative agent [7]. For these reasons, alternative assays taking advantage of PLT functional properties, such as delayed hemolysis and antibody-based hemolysis neutralization test, have been developed [8, 9]. Liquid chromatography with electrospray ionization-tandem mass spectrometric detection (LC-ESI-MS/MS) has also great potential for rapid, sensitive, and unambiguous identification of PLT in contaminated material. One of the drawbacks for its use would be the necessity to relate toxin concentration with actual toxicity in order to evaluate the associated risk, while the fact that analytical methods require very expensive instruments and specialized personnel should also be taken into account.

In this work we set up a cell viability assay to test PLT or PLT-analog activity in different naturally contaminated matrices by using two cellular models; a rat-derived hepatocytes cell line (Clone 9) and BE (2)-M17 human neuroblastoma cells. 


\section{EXPERIMENTAL}

\section{Materials}

Palytoxin standard from Palythoa tuberculosa was purchased from Wako (Osaka, Japan). Okadaic acid was from Alexis Corporation (Lausen, Switzerland) and Alamar Blue was purchased from Biosource International (Nivelles, Belgium).

Culture media for neuroblastoma cells, specifically Eagle`s Minimum Essenial Medium (EMEM) and Ham's F-12 supplemented with glutamine, non-essential aminoacids, gentamicin and amphotericin B were obtained from Biochrom AG (Berlin, Germany).

Clone 9 cells culture media, namely Nutrient mixture F-12 Ham Kaighn's modification, streptomycin sulphate salt and penicillin $\mathrm{G}$ potassium salt were purchased from Sigma (Madrid, Spain) and bovine serum was from Gibco (Barcelona, Spain).

All other reagents were purchased either from Sigma-Aldrich or Panreac (Barcelona, Spain).

\section{Ostreopsis cf siamensis crude extracts}

Ostreopsis cf siamensis were collected as epiphytic to macroalgae at several locations along andalusian coast in Spain. Seawater containing the macroalgae sample was vigorously shaken to detach the epiphytic organisms. Clonal isolates were obtained by transferring individual cells through sterile seawater washes with a capillary pipette. After the washes, every single cell was similarly transferred into a microtitter containing 300 $\mu l$ of sterile L1 medium.

Clonal cultures of Ostreopsis cf siamensis were established in L1 medium [10]. Cultures were grown at $18 \pm 1^{\circ} \mathrm{C}$ and with a $14: 10 \mathrm{~h}$ light:dark photoperiod. Illumination was provided by cool white fluorescent lamps. The cultures were shaken twice a day.

Ostreopsis cells were collected from the culture using $20 \mu \mathrm{m}$ mesh plankton net. The extract was further concentrated by centrifugation. The supernatant was removed and pellet was re-suspended with methanol [methanol:pellet 3:1 (v/v)]. This extract was stored at $-14^{\circ} \mathrm{C}$ until analyzed.

\section{Mussels collection and extraction}

Mussels (Mytilus galloprovincialis) were collected from North Aegean coasts in Greece from the area of Nea Iraklitsa, Kavala where Ostreopsis spp was recorded in high abundances during the period of summer - late autumn of 2006. Extracts for LC-MS assays were prepared from $2 \mathrm{~g}$ mussel homogenate (whole flesh) by duplicate extraction with $100 \% \mathrm{MeOH}$. The first extraction was carried out by using a vortex mixer ( $3 \mathrm{~min}$ at full speed), adding $9 \mathrm{~mL}$ of $\mathrm{MeOH} 100 \%$. After centrifugation at 4500 r.p.m. for $8 \mathrm{~min}$ at $20^{\circ} \mathrm{C}$, the supernatant was transferred into a volumetric flask. The second extraction was carried out by using high-speed homogenizer at 10000 r.p.m for 1 min, adding another $9 \mathrm{~mL}$ and centrifuging using the previously mentioned conditions. Later the supernatant was also transferred into the same volumetric flask containing the supernatant obtained in the first extraction 
and the combined phases were made up to $20 \mathrm{~mL}$. These extracts were also used in the viability test.

\section{Clone 9 rat hepatocytes}

Rat hepatocytes from the cell line Clone 9 (ECACC $\mathrm{N}^{\mathrm{o}}$ 88072203) were grown on Nunc $60 \mathrm{~mm}$ tissue culture plates (Roskilde, Denmark) with a nutrient mixture F-12 Ham Kaighn's modification supplemented with 2.5 $\mathrm{g} / \mathrm{L} \mathrm{NaHCO}_{3}, 28 \mathrm{mg} / \mathrm{L}$ streptomycin sulphate salt, $17 \mathrm{mg} / \mathrm{L}$ penicillin $\mathrm{G}$ potassium salt and 10\% fetal bovine serum $\mathrm{pH}$ 7.2. Cells were cultured in 60 $\mathrm{mm}$ tissue culture plates, maintained at $37^{\circ} \mathrm{C}$ in a humidified atmosphere at $5 \% \mathrm{CO}_{2}$ and were weekly subcultured by transferring released cells with the addition of $0.1 \%$ trypsin-EDTA.

\section{BE(2)-M17 neuroblastoma cells}

Human neuroblastoma cells BE(2)-M17 were routinely grown in EMEM : Ham's F12 (1:1) medium with $2 \mathrm{mM}$ L-glutamine, 1\% non essential amino acids, $10 \%$ fetal bovine serum, $50 \mu \mathrm{g} / \mathrm{ml}$ gentamicine and $50 \mathrm{ng} / \mathrm{ml}$ amphotericin B. Cells were cultured in Nunc $25 \mathrm{~cm}^{2}$ tissue culture flasks (Roskilde, Denmark), maintained at $37^{\circ} \mathrm{C}$ in a humidified atmosphere at $5 \%$ $\mathrm{CO}_{2}$ and were weekly subcultured by transferring released cells with the addition of $0.1 \%$ trypsin-EDTA.

\section{Viability assay}

Metabolic activity of Clone 9 or neuroblastoma cells was measured by using Alamar blue. This compound becomes fluorescent when reduced, without affecting cell integrity [11]. This way, cell metabolic rate can be proportionally evaluated by measurement of the fluorescence intensity.

Cells were seeded on to Corning Costar 96-well plates (Schiphol-Rijk, The Netherlands). After $24 \mathrm{~h}$ of attaching time, standard PLT, O. siamensis crude extracts $(1: 100$ dilutions $(\mathrm{A}, \mathrm{B}, \mathrm{C}, \mathrm{D}$ and $\mathrm{E}))$ or mussel extracts $(1: 5$ dilution) were added to the cells. In the experiments with ouabain, cells were preincubated with $1 \mathrm{mM}$ of this compound for 30 minutes. Finally, a 1:10 dilution of Alamar Blue was added and fluorescence was measured by using a microplate fluorescence reader FL600 (Bio-Tek/ Vermont, U.S.A.). Fluorescence was recorded by using filters of $530 / 25 \mathrm{~nm}$ for excitation and $590 / 35 \mathrm{~nm}$ for emission.

Experiments testing OA were included in order to confirm the inhibition specificity of ouabain towards PLT-induced cytotoxicity. $500 \mathrm{nM}$ was the concentration selected based on the dose-response curve of OA cytotoxic effect (data not shown).

Results are presented as percentage of fluorescence versus its respective control (cells, culture media and treatment vehicle); mean values \pm S.E.M, with $n \geq 3$.

\section{Mouse BioAssay (MBA)}

Mouse Bioassays were conducted as described by Yasumoto et al [12]. Samples 048, 054 and 056 were tested also with the n-butanolic extract obtained with the protocol described in Aligizaki et al 2008 [7]. 
All animal manipulations were performed in accordance to the EU Directive 86/609/EC (1986), under official license from the Prefectural Veterinary Service of Thessaloniki, Greece.

\section{Hemolysis Neutralization Assay (HNA)}

Hemolysis assays were carried out as described previously [7] using sheep erythrocytes.

\section{Liquid-chromatography-mass spectrometric analysis (LC-MS/MS)}

Palytoxin analysis was carried out using a HPLC system Shimadzu (Shimadzu corporation, Kyoto, Japan) which consists of two pumps (LC10ADvp), auto-injector (SIL-10ADvp) and a column oven (CTO-10ACvp) coupled to a 3200QTrap LC/MS/MS system (Applied Biosystems), which consists of a hybrid quadrupole-linear ion trap mass spectrometer equipped with an atmospheric pressure ionization fitted with an electrospray ionization source (ESI, Turbo V source). LC conditions was based on the method proposed by Ciminiello [5] A $5 \mu \mathrm{m}$ C18 column $(150 \times 2 \mathrm{~mm})$ was used at $20^{\circ} \mathrm{C}$ with a flow rate of $0.2 \mathrm{~mL} / \mathrm{min}$. Eluent $\mathrm{A}$ was water and eluent B was 95\% acetonitrile/water, both eluents containing $30 \mathrm{mM}$ acetic acid. Separations were performed by running a linear gradient elution, starting with $20-100 \%$ B for $10 \mathrm{~min}$, followed by a $4 \mathrm{~min}$ hold at $100 \% \mathrm{~B}$, decreasing to $20 \%$ B over $5 \mathrm{~min}$. Mass spectrometric detection was operated in positive mode monitoring the ions in multiple reaction-monitoring (MRM). The transitions selected for toxin detection were: 912->327 (Declustering Potencial [DP]: 61v / Collision Energy [13]: 43eV) and 1352 ->327 (DP: 76v / $\mathrm{CE}: 75 \mathrm{eV})$.

Detection limit (LOD) was calculated based on a sinal/noise $(\mathrm{S} / \mathrm{N})$ ratio of 3. The LOD value corresponded to $50 \mathrm{ng} \mathrm{PLT} / \mathrm{mL}$.

\section{Statistical analysis}

All experiments were carried out in triplicate. Results were analyzed using the Students's t-test for paired data where appropriate. A probability level of $\leq 0.05$ was set to indicate statistical significance. 


\section{RESULTS}

\section{$\underline{\text { Standard PLT detection }}$}

Initially, the effect of standard PLT on metabolic activity of Clone 9 and neuroblastoma cells was evaluated. In both kinds of cells the experimental procedure was similar. A number of 40,000 cells were seeded on to Costar 96-well plates. After $24 \mathrm{~h}$ of attaching time, controls and cells treated with $0.15,1.5,7.5,15$ or $75 \mathrm{nM}$ PLT were incubated at $37^{\circ} \mathrm{C}$ with the dye Alamar Blue up to $24 \mathrm{~h}$. Fluorescence measurements were taken at 3, 6, 8, 12 and 24 hours after the incubation time was started.

Hepatocytes and neuroblastoma cells treated with PLT showed a dosedependent reduction in the fluorescence intensity (figure 1). This fall in fluorescence intensity is related to viability decrease. An incubation time of $3 \mathrm{~h}$ with $15 \mathrm{nM}$ or $75 \mathrm{nM}$ PLT was enough to induce a fast loss of viability (up to 80\%) on hepatocytes (figure 1a). However neuroblastoma cells still maintained nearly $100 \%$ of viability in these conditions (figure $1 \mathrm{~b}$ ). This result clearly indicates a different cytoxicity effect depending on the cellular model. Nevertheless, in hepatocytes (figure 1c) as well as in neuroblastoma (figure 1d) $24 \mathrm{~h}$ of incubation with $1.5 \mathrm{nM}$ PLT was enough to trigger off a significant and quite equal decrease of fluorescence in relation to the control cells.

PLT binds to $\mathrm{Na}^{+} / \mathrm{K}^{+}$pumps in the plasma membrane of animal cells and opens a cation pathway through the pumps. Ouabain is a potent inhibitor of the $\mathrm{Na}^{+} / \mathrm{K}^{+}$pumps, which also inhibits PLT effects. In order to unequivocally relate the reduction on the metabolic rate of the cells with PLT activity we included ouabain inhibition assays (figure 1). In neuroblastoma cells ouabain pre-treatment blocked the decrease on viability induced by PLT (figure $1 \mathrm{~b}$ and $1 \mathrm{~d}$ ). However, in Clone 9 hepatocytes, ouabain only slightly decreased the viability reduction (figure 1a and 1c).

The dose-response curve for $6 \mathrm{~h}$ incubation with the toxins indicates that hepatocytes are more sensitive to cytotoxic effects of PLTs (figure 1e) than neuroblastoma cells (figure 1f).

\section{PLT or PLT-like compounds detection in Ostreopsis cf siamensis extracts}

After that, we evaluated the accuracy of this test to identify the presence of PLT-like compounds in natural contaminated extracts. All extracts induced reduction in viability in both Clone 9 and neuroblastoma cells. Moreover, ouabain inhibited this effect slightly in Clone 9 (figure $2 \mathrm{a}, 2 \mathrm{~b}, 2 \mathrm{c}, 2 \mathrm{~d}$ and $2 \mathrm{e}$ ) but almost completely in neuroblastoma cells as it did with PLT (figure 2f, $2 \mathrm{~g}, 2 \mathrm{~h}, 2 \mathrm{i}$ and $2 \mathrm{j}$ ).

We also found cytotoxicity in hepatocytes and neuroblastoma with other toxins that could be associated to PLT such as okadaic acid (OA) (figure 3). The specificity of our test for PLTs was demonstrated by the lack of effect of ouabain on the viability decrease induced by $500 \mathrm{nM}$ OA in both cell lines (figure $3 \mathrm{a}$ and $3 \mathrm{~b}$ ). Although ouabain plus okadaic acid seems to induce a slight reduction in the cell viability as compare with OA alone in Clone 9 
cells and protection in neuroblastoma, there are no significant differences between the results of both treatments ( $p>>0.05)$.

Even though hepatocytes seem to be more sensitive to PLT action, we chose neuroblastoma cells to improve our test based on the high inhibition induced by ouabain on the PLT effect in this cellular model. In figure 4 we decreased the number of cells seeded to 5,000 cells/ well. After $24 \mathrm{~h}$ of attaching time, the experimental procedure was as before. Controls and cells treated with PLT were incubated at $37^{\circ} \mathrm{C}$ with the dye Alamar Blue up to $24 \mathrm{~h}$. However, in this case, we found a loss of viability after $24 \mathrm{~h}$ incubation with very low concentrations of PLTs (0.015 nM) (figure 4b). Even more, $0.15 \mathrm{nM}$ PLT already induce a viability loss of $20 \%$ after an incubation time of just only 4 $\mathrm{h}$ (figure 4b). The dose-response curve corroborates the increase in sensitivity of the test after reducing the number of cells (figure 4c). We also confirmed the specificity of the method in these experimental conditions by the lack of effect of ouabain on the decrease of viability induced by $500 \mathrm{nM}$ OA (figure $4 \mathrm{~d}$ ).

$O$. cf siamensis crude extracts were tested again in the new condition obtaining a clear increase in sensibility (figure 5). All the extracts triggered a sharp decrease in the metabolic rate of the cells from the first fluorescent measurement ( $4 \mathrm{~h}$ of incubation). At this incubation time, they showed a largely increased cytotoxicity completely inhibited when neuroblastoma cells had been pre-treated with $1 \mathrm{mM}$ ouabain (figure 5). It is interesting to point out that in the case of extract A inhibition by ouabain after $6 \mathrm{~h}$ incubation was incomplete (figure 5a). Similar lack of inhibition was observed with 15 $\mathrm{nM}$ and $75 \mathrm{nM}$ PLT (figure 4a).

In figure $5 f$ we present the quantity of PLT-equivalents per cells for each extract calculated by using the linear relationship shown in Figure 4c. Taking into account those data, an average of $4.103 \pm 1.2 \mathrm{pg}$ PLTequivalents/ cell was calculated using the average number of cells in all crude extracts.

\section{$\underline{\text { PLT or PLT-like compounds detection in mussels extracts }}$}

Also, we analyzed some methanolic extracts from mussels collected along a North Aegean coast in Greece (numbered from 48 to 56), where Ostreopsis spp were found in the last years. All extracts displayed a clear reduction in the metabolic rate of neuroblastoma cells after $48 \mathrm{~h}$ of incubation time but only the effect of $48,49,50,51,52$ and 53 were significantly inhibited by ouabain (figure 6a). The cytotoxic effect of the extracts 54 and 55 was only partially inhibited by ouabain, while no inhibition was observed by the pretreatment with ouabain before the addition of the extract 56. Although some protective effect of the pre-treatment with ouabain can be observed with the extracts 54, 55 and 56 (chiefly extract 55), no significant differences were proved with respect the treatments with the extracts. In fact, $p$ values for paired data were all $>0.05$ for the Student's t-Test. However, the effect of the extracts $48,49,50,51,52$ and 53 were significantly different from the effect of these extracts with pre-treatment. In this case, $p$ values for paired data were all $<0.05$. 
Applying a dose response curve for palytoxin at $48 \mathrm{~h}$ of incubation (figure $6 \mathrm{~b})$, we could estimate the toxin concentration in the mussel extracts that were positive in our test (samples 48-53). This concentration was expressed in $\mathrm{ng} / \mathrm{mL}$ of PLT equivalents (table 1 ).

As a comparative study, methanolic mussels' extracts were analyzed by LCMS, MBA and HNA (table 1). No PLT was detected in any sample by LC-MS. However, okadaic acid (OA) was detected in extract $56(13 \mathrm{ng} / \mathrm{mL})$. All samples were tested and found positive by MBA Protocol (A)[12] as acetonic extracts. N-butanol extracts from samples 48, 54 and 56 were found to be clearly positive for PLT-like compounds in both MBA Protocol (B) and delayed hemolysis neutralization assay. 


\section{DISCUSSION}

The Na+/ K+ pump is the common and specific target of two kinds of natural toxins, heart glycosides and PLT [14]. Heart glycosides such as ouabain bind to the pump when its sodium binding sites are open to the extracellular side, thereby locking two sodium ions into the pump. Also ouabain was demonstrated to inhibit the action of PLT[15]. PLT binds to the $\mathrm{Na}+/ \mathrm{K}+$ ATPase pump and converts it into a cation-selective ion channel [16-19]. This action triggers numerous cytotoxic effects such as cytoskeleton disturbing [20] or intracellular $\mathrm{Ca}++$ increase [21]. We found that preincubation with ouabain prevents the cytotoxic effects induced by PLT. Based on that, we present a viability method to test PLTs by using the metabolic rate indicator Alamar Blue [11]. This dye allows a continuous measurement of the cell viability because it is no toxic for the cells unlike other cytotoxicity indicators [22, 23].

PLT effects were comparatively tested in two cellular models; a rat hepatic cell line (Clone 9) widely used in metabolic studies [24] and human neuroblastoma BE-(2)-M17, excitable cells with a great referenced potential for toxicity evaluation of many compounds $[25,26]$. In this case, we take advantage of the easiness to obtain cells from a cell line versus the laborious isolation procedure of erythrocytes for the delayed hemolytic assay [7].

Changes in the cell metabolic rate indicated a dose-dependent decrease of viability in both cell types. However, rat hepatic cells displayed a higher sensitivity to the action of the toxin. Habbermann et al demonstrated a species-PLT potency relationship showing that rat erythrocytes were more sensitive than those of human, cattle or dog [16].

The usefulness of the viability assay with Alamar Blue for detection of PLT or PLT-like compounds was tested with some crude extracts of $O$. cf siamensis obtained after culture of dinoflagellates harvested on the southern coast of Spain. Unequivocally, all crude extracts tested had a high cytotoxic effect that was inhibited by ouabain in neuroblastoma cells. However, as it was previously observed with PLT, this glycoside did not manage to completely avoid the toxic effect of extracts in rat hepatocytes. This lack of effectiveness of ouabain in the rat hepatic cell line can be attributed to the reported species- and isoform-dependent potency of this glycoside [27]. There are 4 alpha-subunit isoforms of the Na+ K+- ATPase, the binding site of ouabain, which is expressed in the organisms attending to the kind of tissue and specie. The four alpha peptide isoforms have similar high ouabain affinities with $\mathrm{K}_{\mathrm{d}}$ around $1 \mathrm{nM}$ in almost all mammalian species. However rodents express an alpha 1 isoform [28] 100fold less sensitive to ouabain [13]. It could be considered that the alpha-1 isoform in rat and a few other rodents was nearly ouabain-insensitive [29]. This may explain the poor inhibition of PLT-induced cytotoxicity by ouabain in rat hepatocytes, but not the higher toxicity that we found in comparison to the neuroblastoma cells. This is an interesting effect that must be more deeply studied. On the contrary, nervous tissue expresses alpha2 and alpha3 isoforms [30], highly sensitive to cardiac glycosides. This way, neuroblastoma would be the ideal cell model for the specific PLTs detection assay. 
The inhibition by ouabain of the cytotoxic effect induced by crude extracts of $O$. $c f$ siamensis is complete at the first reading time, 4 hours. However, a time-dependent loss of ouabain inhibitory effect indicates the presence of high concentrations of PLT or PLT like compounds in the sample, as we found with the extract $\mathrm{A}$. In this context, a long time viability assay at low density of cells will be appropriate for routine assays, taking into account the high sensitivity of this kind of test. In routine assays we expected concentrations of PLT or PLT -similar to toxins in natural samples (range lower than 40 or $200 \mathrm{ng} / \mathrm{mL}$ ). However, for unexpected high concentrations of PLT or PLT -like toxins in the samples the first reading times may be more reliable for specific detection. However, more precise determination of the toxin concentration can be made by testing the samples with high density of cells.

Two principal characteristics are required for an effective detection method; specificity and sensibility.

1) Viability decrease induced by PLT and PLT-like toxins is specifically inhibited by ouabain. The specificity of our assay was confirmed by the lack of ouabain effect on viability reduction induced by okadaic acid (OA). In this case we chose OA because it has different structure and mechanism of action than PLTs, even though it is a cytotoxic compound. Also both kinds of toxins could appear in the same geographic zone and be accumulated in the same fish and mollusk species, since Prorocentrum sp, a known benthic producer organism of OA, often co-exist with Ostreopsis sp. [31, 32].

2) We set up the number of cells and toxin incubation time to improve the method and increase sensitivity. This way, we can detect $0.15 \mathrm{nM}$ PLT after 4 hours incubation $(0.4 \mathrm{ng} / \mathrm{mL})$. On the top of that, since Alamar Blue is a non-toxic dye, this is a dynamic method as we may keep the incubation of the toxins with the cells up to $72 \mathrm{~h}$. Then we could be able to detect lower concentrations of toxins (up to $0.075 \mathrm{nM}$ PLT, which means $0.2 \mathrm{ng} / \mathrm{mL}$ ). This way, we obtained a very wide detection range between 0.2 and $40 \mathrm{ng} / \mathrm{mL}$ PLT equivalents, including the MU (9 ng).

In these conditions, $O$. cf siamensis crude extracts and even extracts from mussels can be tested for the presence of PLT and PLT like compounds.

All tested extracts from the dinoflagellates were clearly positive for the presence of PLT or PLT-like compounds. However, although all the extracts from mussels were cytotoxic, two of them displayed a partially PLTindependent effect. Moreover, sample 56 exerted completely PLTindependent cytotoxicity. This fact could be explained by the presence in the methanolic extract of a different kind of toxin such as OA as the LC-MS analysis indicated. Samples 56 (as well as samples 48, 54) resulted clearly positives for MBA and delayed hemolysis neutralization assays pointing to the presence of PLT or PLT-like compounds. In this case, MBA and delayed hemolysis neutralization assays were carried out in the same group of mussels but making $\mathrm{n}$-butanolic extraction. PLT-like compounds could be more concentrated in this fraction, and this fact could be responsible of the differences on the results obtained with this sample in the LC-MS analysis and our assays. However, a routine assay for testing natural samples of 
shellfish may require an initial simple extraction such as with $100 \%$ methanol not to exclude other toxins such as DSP.

Calculation of PLT-equivalents for each extract was also possible with our method. The average of all the $O$. cf siamensis crude extracts was $4.103 \mathrm{pg}$ PLT-equivalents / cell. This quantity is very similar to the content of PLT and PLT analogues obtained in other recent studies [6] for crude extracts from Ostreopsis spp. Currently, we use this method in our laboratory to evaluate the production of PLT and PLT-like compounds by Ostreopsis siamensis cultures, founding until now concentrations in the range from $2.76 \pm 1.18$ up to $17.23 \pm 5.50 \mu \mathrm{g}$ PLT equivalents $/ \mathrm{mL}$.

The new method presented here is sensitive detecting PLT or PLT-like compounds in a natural sample of dinoflagellates or mussels but also indicate the presence of other toxins and differentiate them from PLT. The action mechanism of palytoxin (PLT) is specific and well defined. PLT links to the membrane $\mathrm{Na}+/ \mathrm{K}+-$ ATPase pump [16, 17, 19]. Many studies reported that the action of PLT is blocked totally by ouabain, a cardiac glycoside that links to $\mathrm{Na}+\mathrm{K}+$ ATPase [15]. This propriety is unique in the marine toxins world and is the starting point of our detection method. Many toxic compounds display acute fall in metabolic rate and then, viability decrease in cells. However, only a group of toxins trigger sharp cytotoxicity completely inhibited by ouabain; PLT and PLT-like compounds such as ostreocin D or ovatatoxin-A. Complexity in the PLT molecule makes possible the existence of many PLT analogues. With our method, three scenes can occur with the samples that result cytotoxic:

a) The cytotoxicity is no inhibited by ouabain, then the sample contains non PLT-like toxins.

b) The cytotoxicity is partially inhibited by ouabain, therefore the sample contains at least two types of compounds; PLT-like and non PLT-like compounds. In this case, we detect the presence of PLT based on the part of the cytotoxic effect inhibited by ouabain, however we can not infer a PLT-equivalents concentration because of the impossibility to assign the portion of cytotoxicity from which PLT-like compounds are responsible.

c) The cytotoxicity is completely inhibited by ouabain, so the sample contains only PLT or PLT-like compounds and we can calculate their concentration in the sample.

In short, in a sample we can differentiate the cytotoxic effect due to PLT or PLT-like compounds from this of any other toxin based on its specific inhibition by ouabain.

In this study we set up an easy, fast, sensitive, specific and dynamic viability assay in neuroblastoma cells to test PLTs and to detect PLT-like compounds in crude extracts with many advantages, such as the possibility of simultaneous testing many samples in microtiter plates and the wide range for detection that offers. 


\section{REFERENCES}

1 Onuma, Y., Satake, M., Ukena, T., Roux, J., Chanteau, S., Rasolofonirina, N., Ratsimaloto, M., Naoki, H. and Yasumoto, T. (1999) Identification of putative palytoxin as the cause of clupeotoxism. Toxicon $37,55-65$

2 Moore, R. E. and Scheuer, P. J. (1971) Palytoxin: a new marine toxin from a coelenterate. Science 172, 495-498

3 Usami, M., Satake, M., Ishida, S., Inoue, A., Kan, Y. and Yasumoto, T. (1995) Palytoxin analogs from the dinoflagellate Ostreopsis siamensis. J. Am. Chem. Soc. $117,5389-5390$

4 Brescianini, C., Grillo, C., Melchiorre, N., Bertolotto, R., Ferrari, A., Vivaldi, B., Icardi, G., Gramaccioni, L., Funari, E. and Scardala, S. (2006) Ostreopsis ovata algal blooms affecting human health in Genova, Italy, 2005 and 2006. Euro Surveill 11, E060907 060903

5 Ciminiello, P., Dell'Aversano, C., Fattorusso, E., Forino, M., Magno, G. S., Tartaglione, L., Grillo, C. and Melchiorre, N. (2006) The Genoa 2005 outbreak. Determination of putative palytoxin in Mediterranean Ostreopsis ovata by a new liquid chromatography tandem mass spectrometry method. Anal Chem 78, 6153-6159

6 Ciminiello, P., Dell'aversano, C., Fattorusso, E., Forino, M., Tartaglione, L., Grillo, C. and Melchiorre, N. (2007) Putative Palytoxin and Its New Analogue, Ovatoxin-a, in Ostreopsis ovata Collected Along the Ligurian Coasts During the 2006 Toxic Outbreak. J Am Soc Mass Spectrom

7 Aligizaki, K., Katikou, P., Nikolaidis, G. and Panou, A. (2008) First episode of shellfish contamination by palytoxin-like compounds from Ostreopsis species (Aegean Sea, Greece). Toxicon 51, 418-427

8 Bignami, G. S. (1993) A rapid and sensitive hemolysis neutralization assay for palytoxin. Toxicon $31,817-820$

9 Bignami, G. S., Raybould, T. J., Sachinvala, N. D., Grothaus, P. G., Simpson, S. B., Lazo, C. B., Byrnes, J. B., Moore, R. E. and Vann, D. C. (1992) Monoclonal antibody-based enzyme-linked immunoassays for the measurement of palytoxin in biological samples. Toxicon 30, 687-700

10 Guillard and Hargraves (1993) Stichochrysis immobilis is a diatom, not a chrysophyte. Phycologia 322, 79-99

11 Ahmed, S. A., Gogal, R. M., Jr. and Walsh, J. E. (1994) A new rapid and simple non-radioactive assay to monitor and determine the proliferation of lymphocytes: an alternative to $[3 \mathrm{H}]$ thymidine incorporation assay. J Immunol Methods 170 , 211-224

12 Yasumoto, T., Oshima, Y. and Yamaguchi, M. (1978) Occurrence of a new type of shellfish poisoning in the Tohuku District. Bull. Jap. Soc. Sci. Fish. 44, 12491255

13 Blanco, G. and Mercer, R. W. (1998) Isozymes of the Na-K-ATPase: heterogeneity in structure, diversity in function. Am J Physiol 275, F633-650

14 Hilgemann, D. W. (2003) From a pump to a pore: how palytoxin opens the gates. Proc Natl Acad Sci U S A 100, 386-388

15 Habermann, E. and Chhatwal, G. S. (1982) Ouabain inhibits the increase due to palytoxin of cation permeability of erythrocytes. Naunyn Schmiedebergs Arch Pharmacol 319, 101-107 
16 Habermann, E., Hudel, M. and Dauzenroth, M. E. (1989) Palytoxin promotes potassium outflow from erythrocytes, HeLa and bovine adrenomedullary cells through its interaction with $\mathrm{Na}+, \mathrm{K}+$-ATPase. Toxicon 27, 419-430

17 Hirsh, J. K. and Wu, C. H. (1997) Palytoxin-induced single-channel currents from the sodium pump synthesized by in vitro expression. Toxicon 35, 169-176

18 Scheiner-Bobis, G., Meyer zu Heringdorf, D., Christ, M. and Habermann, E. (1994) Palytoxin induces K+ efflux from yeast cells expressing the mammalian sodium pump. Mol Pharmacol 45, 1132-1136

19 Wang, X. and Horisberger, J. D. (1997) Palytoxin effects through interaction with the Na,K-ATPase in Xenopus oocyte. FEBS Lett 409, 391-395

20 Ares, I. R., Louzao, M. C., Vieytes, M. R., Yasumoto, T. and Botana, L. M. (2005) Actin cytoskeleton of rabbit intestinal cells is a target for potent marine phycotoxins. J Exp Biol 208, 4345-4354

21 Louzao, M. C., Ares, I. R., Vieytes, M. R., Valverde, I., Vieites, J. M., Yasumoto, T. and Botana, L. M. (2007) The cytoskeleton, a structure that is susceptible to the toxic mechanism activated by palytoxins in human excitable cells. Febs J 274, 1991-2004

22 Carmichael, J., DeGraff, W. G., Gazdar, A. F., Minna, J. D. and Mitchell, J. B. (1987) Evaluation of a tetrazolium-based semiautomated colorimetric assay: assessment of radiosensitivity. Cancer Res 47, 943-946

23 Davies, P., Fox, R. I., Polyzonis, M., Allison, A. C. and Haswell, A. D. (1973) The inhibition of phagocytosis and facilitation of exocytosis in rabbit polymorphonuclear leukocytes by cytochalasin B. Lab Invest $28,16-22$

24 Louzao, M. C., Espina, B., Vieytes, M. R., Vega, F. V., Rubiolo, J. A., Baba, O., Terashima, T. and Botana, L. M. (2007) "Fluorescent glycogen" formation with sensibility for in vivo and in vitro detection. Glycoconj $\mathrm{J}$

25 Cagide, E., Louzao, M. C., Ares, I. R., Vieytes, M. R., Yotsu-Yamashita, M., Paquette, L. A., Yasumoto, T. and Botana, L. M. (2007) Effects of a synthetic analog of polycavernoside $\mathrm{A}$ on human neuroblastoma cells. Cell Physiol Biochem 19, 185-194

26 Louzao, M. C., Cagide, E., Vieytes, M. R., Sasaki, M., Fuwa, H., Yasumoto, T. and Botana, L. M. (2006) The sodium channel of human excitable cells is a target for gambierol. Cell Physiol Biochem 17, 257-268

27 Gupta, R. S., Chopra, A. and Stetsko, D. K. (1986) Cellular basis for the species differences in sensitivity to cardiac glycosides (digitalis). J Cell Physiol 127, 197-206

28 Allen, J. C., Abramowitz, J. and Koksoy, A. (2003) Low concentrations of ouabain activate vascular smooth muscle cell proliferation. Ann N Y Acad Sci 986, 504-508

29 Hansen, O. (2003) Rat resistance vessels preferentially contain the ouabaininsensitive alpha1 isoform of Na,K-ATPase. Ann N Y Acad Sci 986, 642-643

30 Lingrel, J. B. and Kuntzweiler, T. (1994) Na+,K(+)-ATPase. J Biol Chem 269, 19659-19662

31 Farstad, D. J. and Chow, T. (2001) A brief case report and review of ciguatera poisoning. Wilderness Environ Med 12, 263-269

32 Lewis, R. J. and Holmes, M. J. (1993) Origin and transfer of toxins involved in ciguatera. Comp Biochem Physiol C 106, 615-628 


\section{ACKNOWLEDGEMENTS}

This work was funded with the following grants:

Contract grant sponsor: Ministerio de Ciencia y Tecnología, Spain; Contract grant numbers: AGL2006-08439/ALI , AGL2005-23689-E, AGL2005-23687-E, AGL200408268-C02-02/ALI, AGL2007-60946/ALI, , REN2003-06598-C02-01

Contract grant sponsor: Xunta de Galicia, Spain; Contract grant numbers: GRC 30/2006 PGIDIT05PXIC26101PM， PGIDIT05PXIC26102PM， PGIDIT05PXIC26102PN, PGIDIT04TAL261005PR, PGIDIT 07MMA006261PR and PGIDT07CSA012261PR. EU VIth Frame Program; Grant Number: IP FOOD-CT-2004-06988 (BIOCOP), STREP FOOD-CT-2004-514055 (DETECTOX) and CRP 030270-2 (SPIES-DETOX). 


\section{TITLES AND LEGENDS FOR FIGURES}

Figure 1: Dose-dependent effect of PLT on Clone 9 rat hepatocytes and $B E(2)-M 17$ human neuroblastoma viability. Rat hepatocytes (a and c) or neuroblastoma cells ( $b$ and $d$ ) were incubated with PLT and Alamar Blue for $24 \mathrm{~h}$. Pre-treatments with $1 \mathrm{mM}$ ouabain were included for all concentration tested where indicated. Doses- response of PLT on Clone 9 rat hepatocytes (e) and BE(2)-M17 neuroblastoma cells (f) after $6 \mathrm{~h}$ of incubation.

Results are expressed as percentage of fluorescence versus controls $(=100 \%)$ (mean \pm S.E.M.; n=3).

Figure 2: Effect of different Ostreopsis cf siamensis crude extracts on the viability of Clone 9 rat hepatocytes (left column) and BE(2)-M17 neuroblastoma cells (right column) and its inhibition by ouabain. Both cell types were incubated for $24 \mathrm{~h}$ with 1:100 dilutions of 5 O. cf siamensis crude extracts. $30 \mathrm{~min}$ pre-treatment with $1 \mathrm{mM}$ ouabain were included when indicated. Results are expressed as percentage of fluorescence versus controls $(=100 \%)($ mean \pm S.E.M.; n=3).

Figure 3: Lack of inhibition of ouabain in the effect of okadaic acid (OA). Rat hepatocytes (a) or neuroblastoma cells (b) were incubated for $6 \mathrm{~h}$ with 500 nM OA. There was a $30 \mathrm{~min}$ pre-treatment with $1 \mathrm{mM}$ ouabain where indicated. Results are expressed as percentage of fluorescence versus controls $(=100 \%)($ mean \pm S.E.M.; $n=3)$.

Figure 4: Dose-dependent effect of PLT on BE(2)-M17neuroblastoma viability at low cell density ( $a$ and $b$ ). Alamar Blue viability assays were carried out as described in materials and methods. Pre-treatments with 1 $\mathrm{mM}$ ouabain were included where indicated. c) Doses-response for $4 \mathrm{~h}$ incubation with PLT on neuroblastoma cells at low cell density. d) Lack of inhibition of ouabain in the effect of okadaic acid (OA). Neuroblastoma cells at low density were incubated for $4 \mathrm{~h}$ with $500 \mathrm{nM}$ OA. There was a $30 \mathrm{~min}$ pre-treatment with $1 \mathrm{mM}$ ouabain where indicated.

Results are expressed as percentage of fluorescence versus controls $(=100 \%)$ (mean \pm S.E.M.; $n=3$ ).

Figure 5: Effect of different Ostreopsis cf siamensis crude extracts on the viability of neuroblastoma cells seeded at low density (a-e). Neuroblastoma cells were incubated for $24 \mathrm{~h}$ with 1:100 dilutions of $5 \mathrm{O}$. cf siamensis crude extracts. There was $30 \mathrm{~min}$ of pre-treatment with $1 \mathrm{mM}$ ouabain were indicated. f) Concentration of palytoxin-like compounds was calculated for each 0. cf siamensis crude extracts taking into account its effects on the viability assays and the doses-response curve.

Results are expressed as percentage of fluorescence versus controls $(=100 \%)$ (mean \pm S.E.M.; n=3). 
Figure 6: Effect of methanolic mussel extracts on the viability of neuroblastoma cells and doses response curve for PLT at $48 \mathrm{~h}$ of incubation. a) Neuroblastoma cells were incubated for $48 \mathrm{~h}$ with 1:5 dilutions of 9 methanolic extracts of mussels collected at North Aegean region. Pretreatment with $1 \mathrm{mM}$ ouabain for 30 min were included for all the extracts. b) Doses response for PLT at $48 \mathrm{~h}$ of incubation. Results are expressed as percentage of fluorescence versus controls $(=100 \%)($ mean \pm S.E.M.; $n=3)$.

Table 1: Comparative table of PLT detected by viability assays, LC-MS analysis, MBA and delayed hemolysis neutralization assay for mussels' extracts. Results of viability assays are presented as concentration of PLT or PLT-like compounds calculated by applying the dose response curve for PLT at $48 \mathrm{~h}$ (figure $5 \mathrm{c}$ ) and expressed in $\mathrm{ng}$ of PLT equivalents/ $\mathrm{mL}$ (mean \pm S.E.M.M $\mathrm{n}=3$ ). Lack of PLT was detected by LC-MS/MS analysis for all methanolic extracts. N-butanolic extracts for 048,054 and 056 samples of mussels collected at the same regions were analyzed by MBA and HNA resulting positives. Also, all samples were positives for MBA after acetonic extraction. 


\section{Figure 1}

a
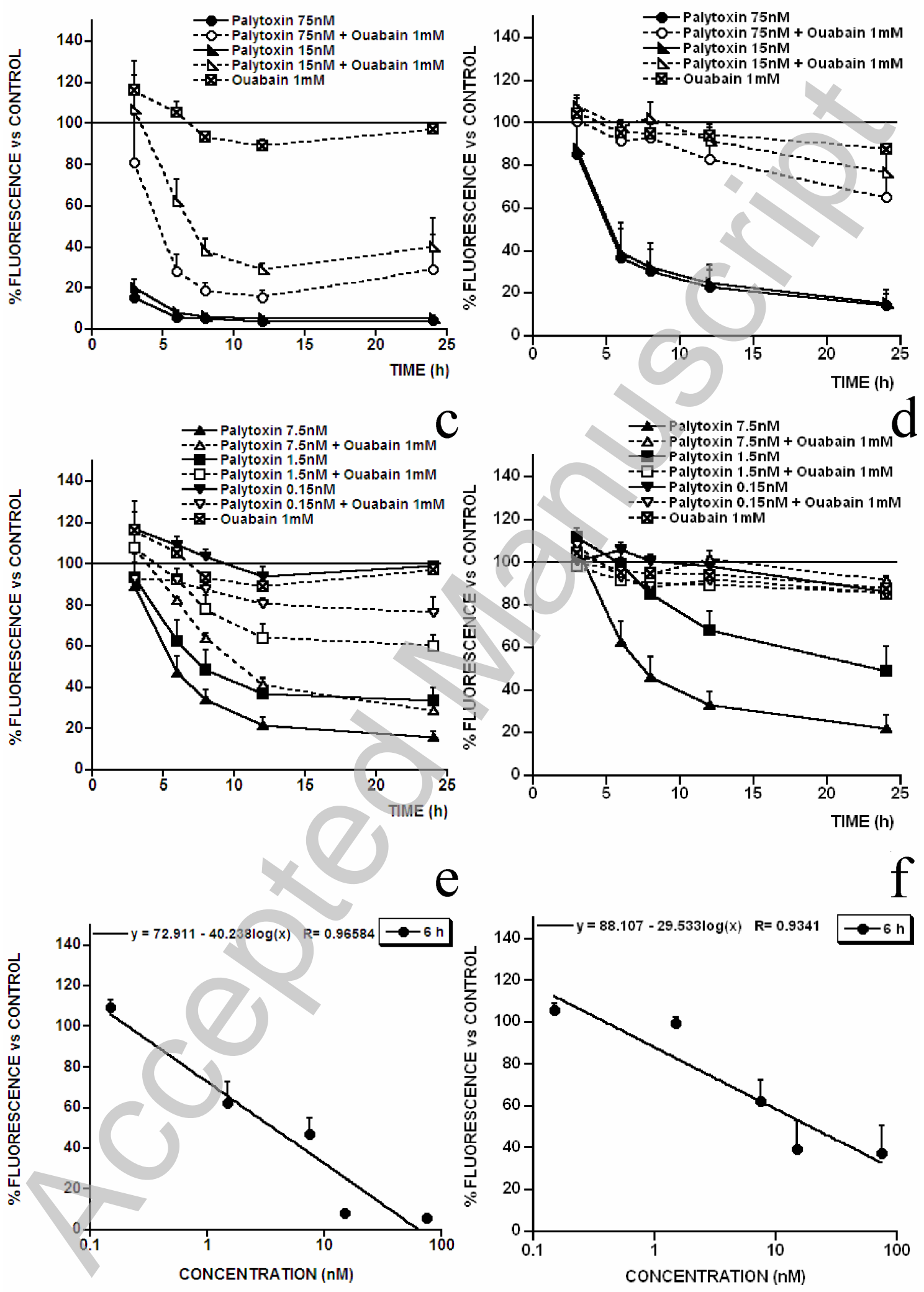

Licenced copy. Copying is not permitted, except with prior permission and as allowed by law.

(C) 2008 The Authors Journal compilation (C) 2008 Biochemical Society 
Figure 2

a

f
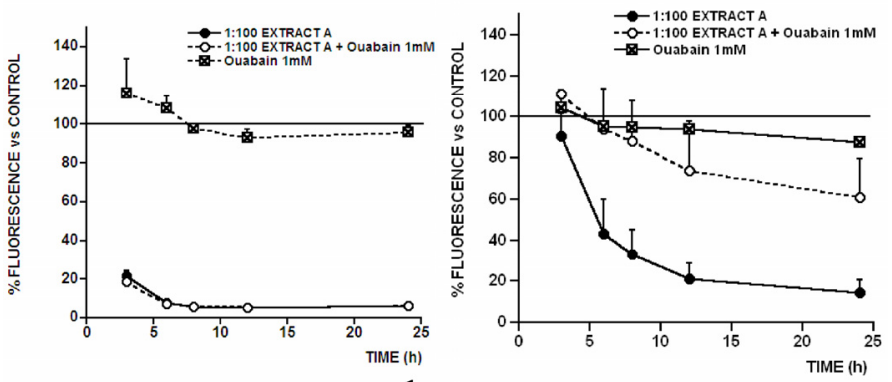

$\mathrm{b}$

$\mathrm{g}$
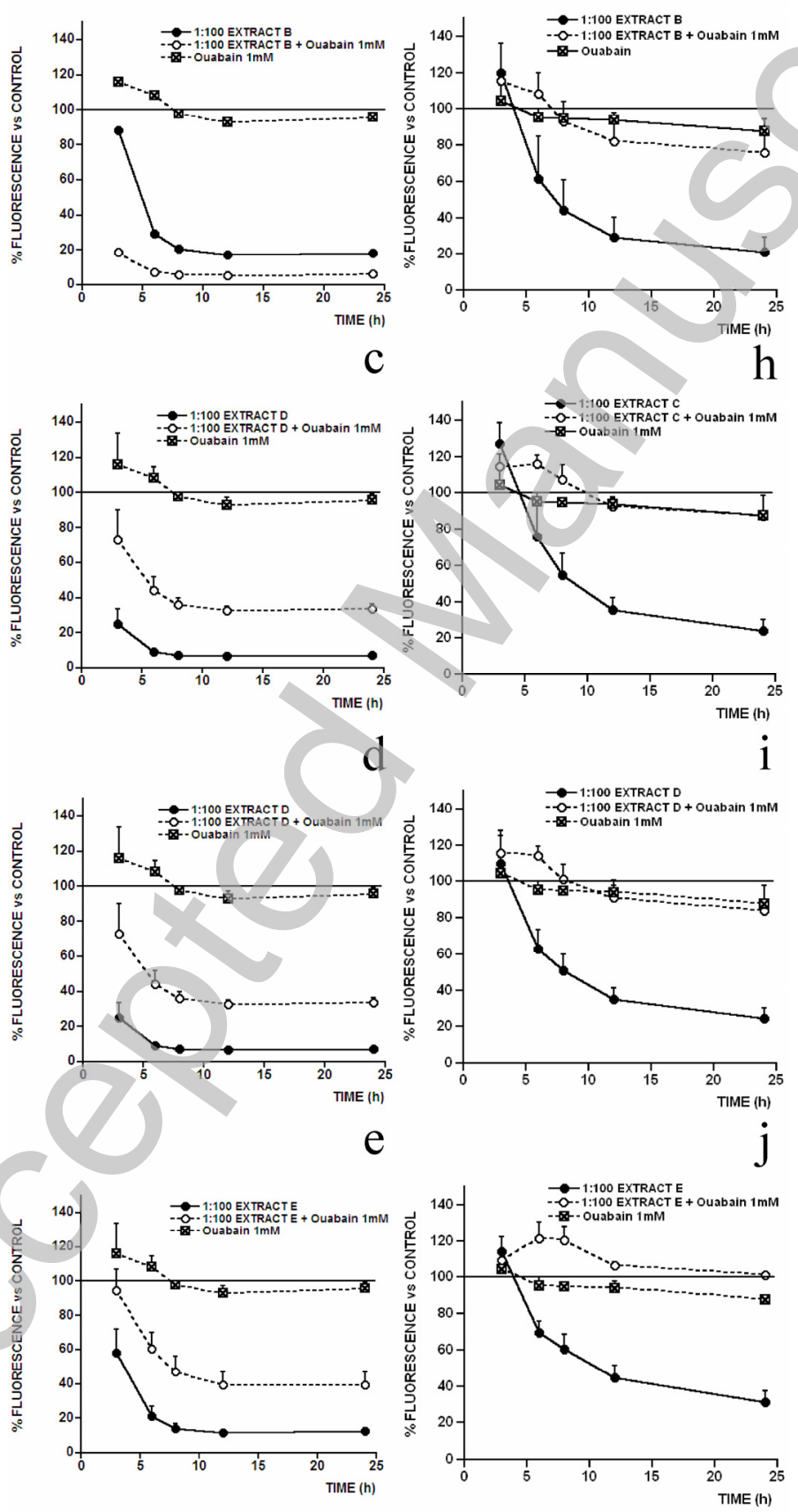


\section{Figure 3}

a
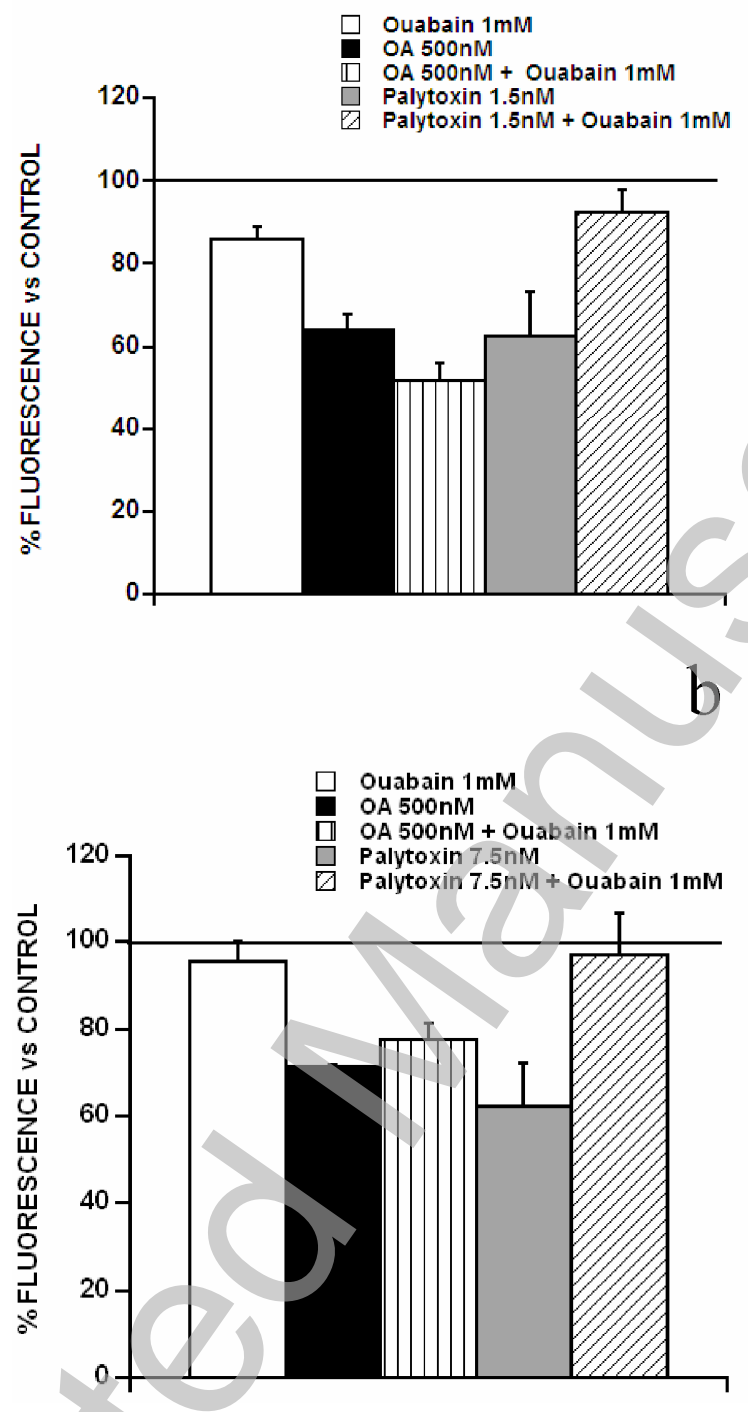


\section{Figure 4}

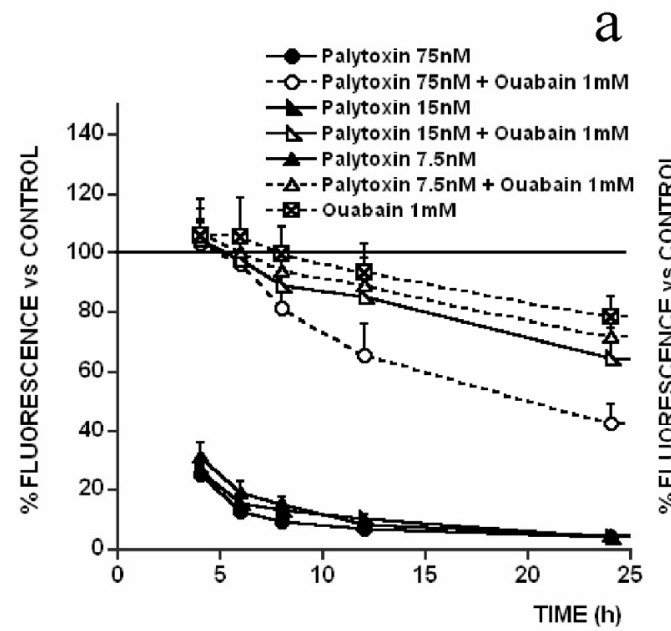

a $\mathrm{C}$
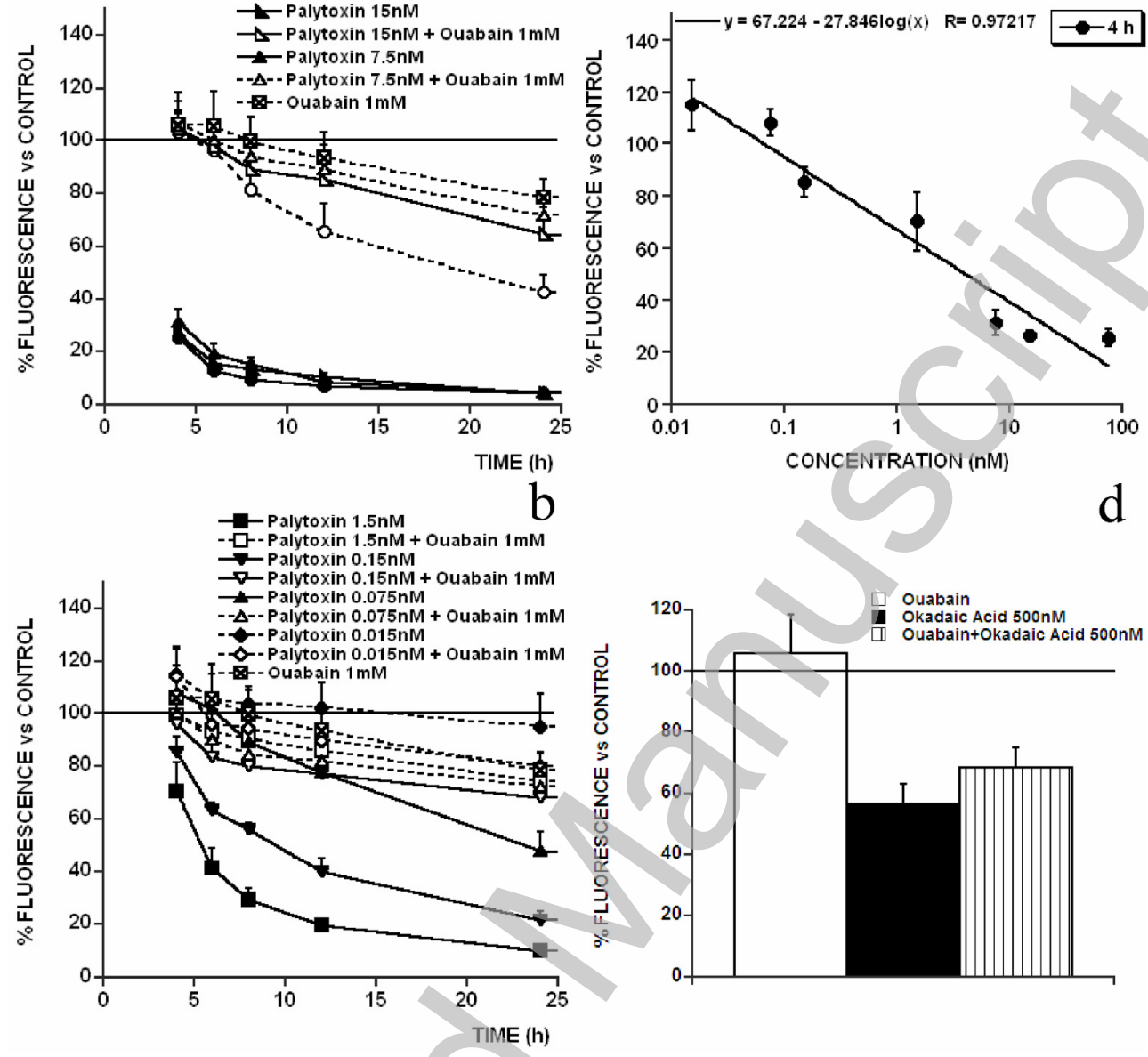

$\mathrm{d}$

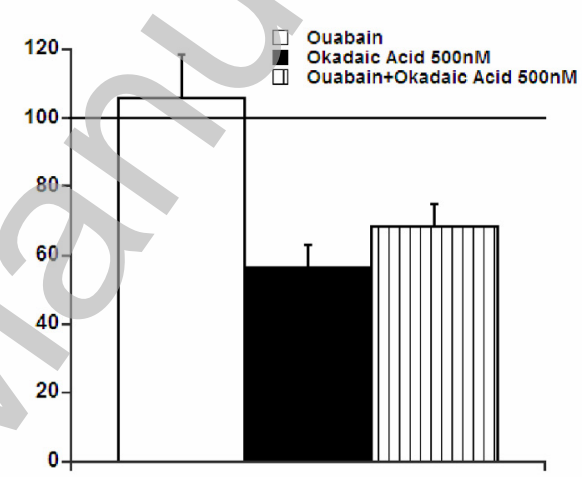

Licenced copy. Copying is not permitted, except with prior permission and as allowed by law. (C) 2008 The Authors Journal compilation (C) 2008 Biochemical Society 


\section{Figure 5}

a

b
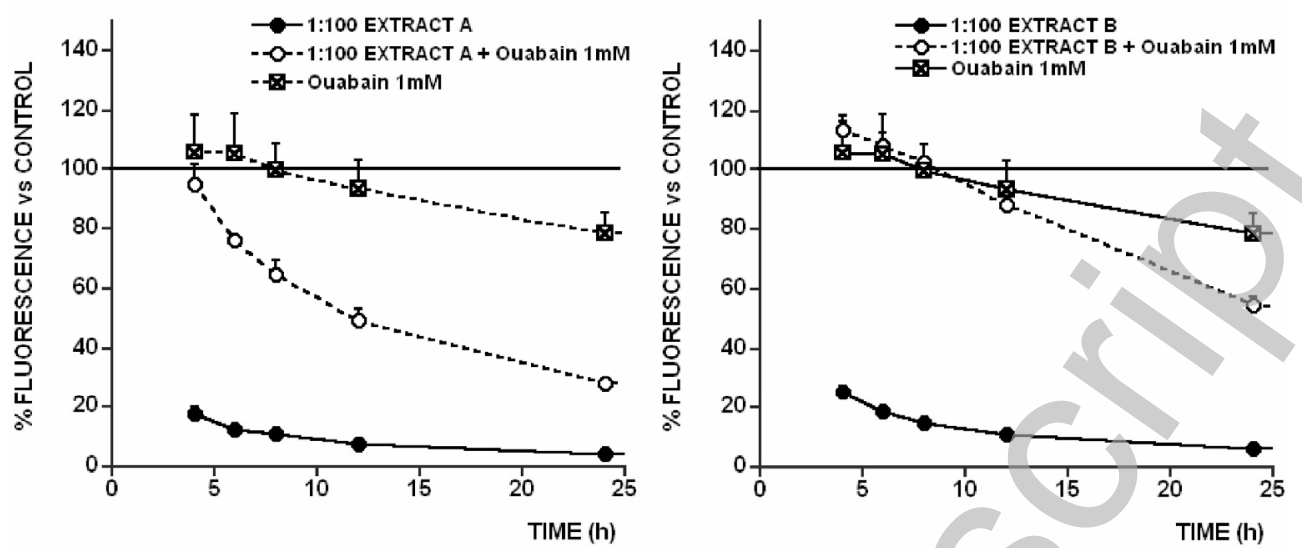

C

d

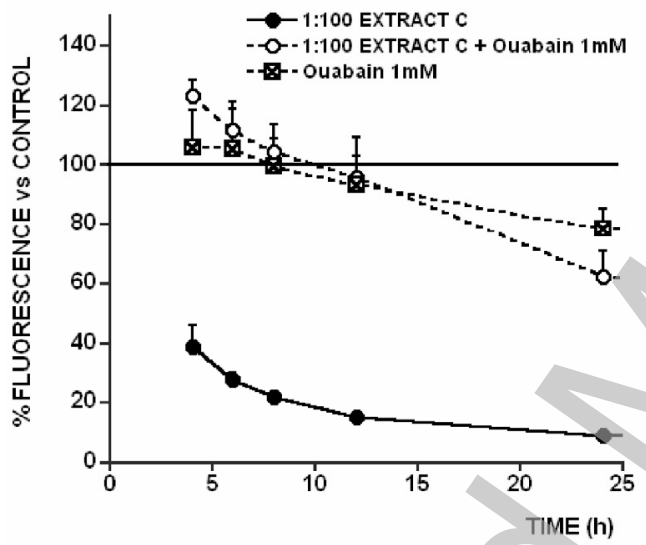

- $1: 100$ EXTRACT D
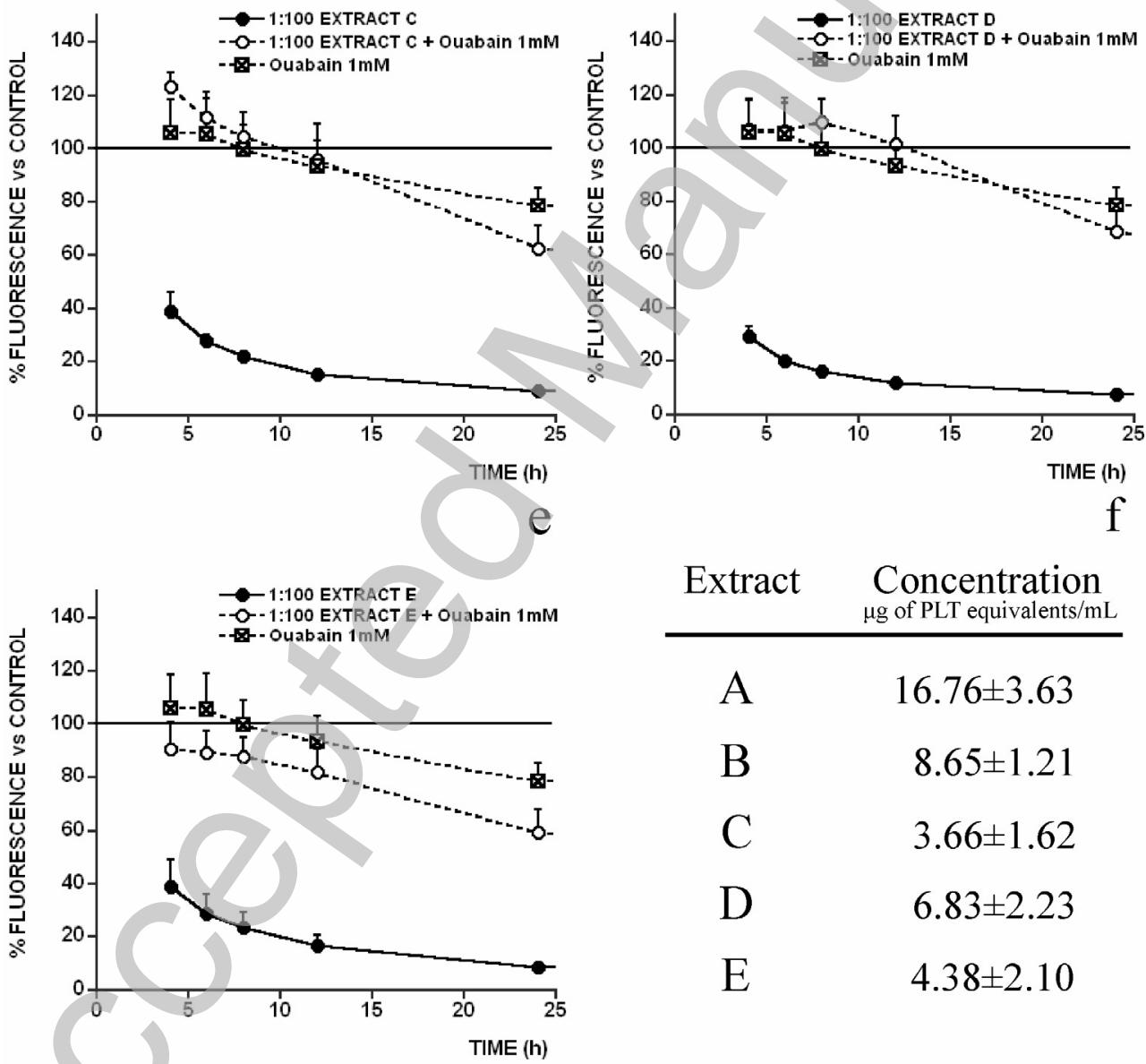

A

$16.76 \pm 3.63$

B

$8.65 \pm 1.21$

C

$3.66 \pm 1.62$

D

$6.83 \pm 2.23$

E

$4.38 \pm 2.10$

Licenced copy. Copying is not permitted, except with prior permission and as allowed by law. 


\section{Figure 6}

a

b
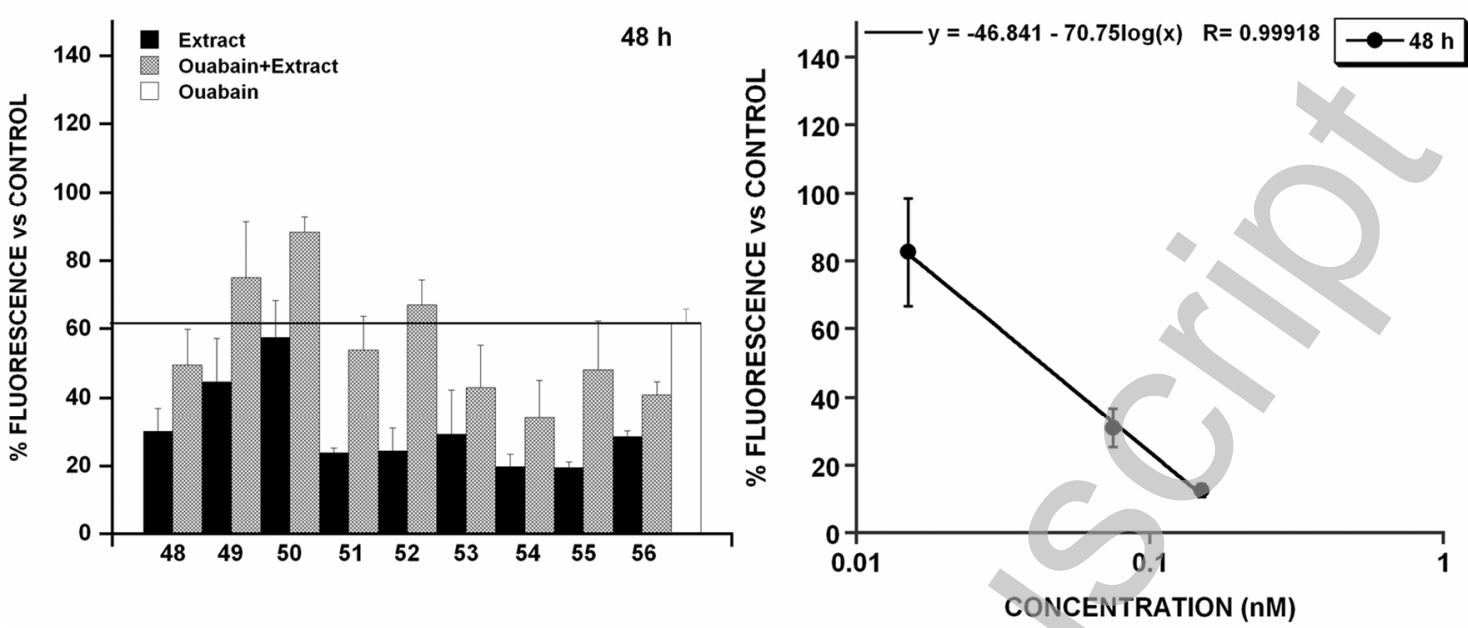
Table 1

\begin{tabular}{|c|c|c|c|c|}
\hline & \multirow{2}{*}{$\begin{array}{c}\text { Cytotoxicity } \\
\begin{array}{c}\text { Methanol } \\
\text { (ng PLTeq/mL) }\end{array} \\
\end{array}$} & \multirow{2}{*}{$\begin{array}{c}\text { LC-MS } \\
\text { Methanol }\end{array}$} & \multirow{2}{*}{$\frac{\text { MBA }}{\text { Acetone }}$} & \multirow{2}{*}{$\begin{array}{l}\text { Hemolysis } \\
\text { n-Butanol }\end{array}$} \\
\hline & & & & \\
\hline 048 & $11.43 \pm 2.21$ & None & $+++^{b}$ & Yes \\
\hline 049 & $7.88 \pm 2.59$ & None & +++ & n.d. \\
\hline 050 & $5.00 \pm 1.45$ & None & ++- & $n d$ \\
\hline 051 & $13.41 \pm 0.60$ & None & +++ & \\
\hline 052 & $13.79 \pm 2.66$ & None & ++ & \\
\hline 053 & $13.03 \pm 4.11$ & None & & \\
\hline 054 & Yes* & None & & Yes \\
\hline 055 & Yes* & None & & n.d. \\
\hline 056 & Yes ${ }^{* *}$ & $O A^{a}$ & & Yes \\
\hline
\end{tabular}

*: Not completely inhibited by ouabain

${ }^{* *}$ : Not inhibited by ouabain

n.d.: Not determined

a: $13 \mathrm{ng} / \mathrm{mL}$ Okadaic Acid (OA)

b: Tested and possitive with $n-B u t a n o l ~ e x t r a c t i o n$ 